\title{
Evaluation of Different Genotypes of Maize (Zea mays L.) on Plant Growth, Flowering, Synchronization and Seed Yield in Relation to Environmental Factors and Seasons
}

\author{
Vikas Verma ${ }^{2}$, B. Ramesh ${ }^{1}$, C.L. Maurya ${ }^{2}$, S.S. Gaurav', \\ Janardan Kumar ${ }^{2}$ and Ashoka Chaudhary ${ }^{2}$ \\ ${ }^{1}$ Department of Seed Science and Technology, CCSU, Meerut (U.P.), India \\ ${ }^{2}$ Chandra Shekhar Azad University of Agriculture and Technology, Kanpur (U.P.), India
}

*Corresponding author

\section{A B S T R A C T}

\section{Keywords \\ Maize, Plant growth, flowering, Synchronization, \\ Seasons, hybrid \\ Seed}

Article Info

Accepted:

15 June 2018

Available Online:

10 July 2018
A field experiment was conducted during 2002 at CCS University, Meerut to study the effect of environmental factors and seasons on plant growth, flowering, Synchronization and seed yield in Six inbreds/OPVs: CM135, CM136, CM137, CM138, CM500, CM600 and two single crosses: CM202xCM111 and CM400xCM300 were evaluated for five characters namely, plant height, Number of leaves per plant, tassel and silk emergence, duration of anthesis, duration of silking and seed yield. The result revealed that plant height, number of leaves was better in kharif than in spring-summer season. Seed yield and duration of anthesis and silking maximum in spring-summer than in kharif season. Parents (CM135, CM136, CM137 and CM138) and the single crosses (CM202xCM111 and CM400xCM300) showed taken duration of anthesis and silking highly in both the seasons. Single crosses (CM202xCM111 and CM400xCM300) give highest yield while parental lines CM600 and CM500 had lowest seed yield.

\section{Introduction}

Globally, maize is the third most important cereal grain after rice and wheat. India ranks $4^{\text {th }}$ in area and $7^{\text {th }}$ in production of maize in the world. The area, production, and productivity of maize in India are $8.6 \mathrm{mha}, 20.5 \mathrm{mha}$, and $2.4 \mathrm{t} / \mathrm{ha}$, respectively in 2010-2011(USDA). In India predominant maize growing states are Andhra Pradesh (20.9\%), Karnataka (16.5\%), Maharashtra (9.1\%), Bihar (8.9), Uttar Pradesh (6.1\%), Madhya Pradesh (5.7\%) and
Himachal Pradesh (4.4\%). Maize in India is predominantly grown during Kharif (monsoon) season, though it can very profitably be grown in rabi (winter) season under frost free areas with mild winter whereas rabi maize is widely cultivated in north Bihar and South India. The readily available starches in maize allow the crop to be widely used in livestock feeds, foods for human consumption, and industrial applications such as alcohols, pharmaceuticals, and bio-fuels (GFO, 2012). 
The productivity of maize in India is just half than the world productivity might be due to unavailability of suitable genotypes under various climatic conditions of India. The adoption of hybrid cultivars for improving the production and availability of hybrid seed, offers possibility of increasing maize productivity in North India states. The present study was under taken in order to explore the possibilities of maize seed production during kharif and spring-summer season.

\section{Materials and Methods}

A field experiment was conducted during 2002 at field of U.P. Seed Corporation limited, Meerut in collaboration CCSU, Meerut to study the effect of environmental factors and seasons on Plant growth, flowering, Synchronization and Seed Yield in Different Genotypes of Maize (Zea mays L.) under North Indian conditions. The present investigation was comprised with eight genotypes of maize including six inbreds viz., CM135,CM136,CM137,CM138,CM500,CM6 00 and two single crosses viz., CM202 xCM111 and CM400xCM300 were sown during spring - summer and kharif. The experiment was evaluated in a randomized block design. Each maize genotype was planted in four rows of 5 meter length. Row to row and plant to plant distance were kept $75 \mathrm{~cm}$ and $25 \mathrm{~cm}$, respectively by thining. All the recommended improved agronomic practices were adopted for raising a good crop. The data were recorded on the following parameters for plant height $(\mathrm{cm})$ after flowering, plant height was recorded on 5 random plants/ replication from the base to the tip of the tassel and mean value was expressed in $\mathrm{cm}$. Number of leaves per plant, total number of leaves per plant was counted at flowering. Tassel and silk emergence, number of days to 50 per cent anthesis and 50 per cent silking was recorded when half of the plants in the plot exhibited tassel and silk emergence. Duration of anthesis, it was recorded as the number of days taken from opening of first spikelet to last spikelet in a tassel. Duration of silking, it was recorded as the number of days from emergence to drying of silk in each cob. Seed yield, at field maturity (18\% moisture content), 35 cobs were selected randomly from each plot, harvested, threshed, and seed yield per cob was calculated and expressed in gm The meteorological data was obtained from Shri Ram Sugarcane Research Center Modipuram Meerut. The analysis of data were divided with their respective root mean square errors and analyzed as per procedure of group of experiment as suggested by Panse and Sukhateme (1967).

\section{Results and Discussion}

Plant height of all the genotypes tested was higher in kharif than that of spring-summer (Table 1). Genotypic differences were significant in both the seasons for plant height. Parental lines of PHM-1 and PHM-2 were taller than the open pollinated varieties (CM500 and CM600) kharif while in springsummer season the open pollinated varieties were slightly taller (Table 1). Vegetative growth in low temperature regimes prolonged vegetative phase due to slow growth and duration of crop in spring-summer season over that in kharif. Number of leaves per plant and its rate of appearance were influenced by temperature regimes (Hollinger, 1981) and length of vegetative phase was closely related to daily average temperature above $6{ }^{\circ} \mathrm{C}$ (Block et al., 1984).In the present investigation, number of leaves per plant expressed marginal difference among seasons and was more in spring-summer as compared to kharif due to mild temperatures during growth (Table 1). It was fairly stable character and genotypic effect was predominant over environmental effect. Kaur et al., (1986) also reported that number of leaves per plant remains constant for a genotype over seasons. Temperature was a critical factor in springsummer season resulting in slow and restricted 
vegetative growth resulting in shorter plant height. Kaur et al., (1986) also reported similar effectof low temperature on vegetative growth. Among genotypes, number of leaves per plant and plant height were higher in single crosses than other parental lines. Number of leaves per plant at flowering exhibited significant difference among genotypes with single crosses having more number of leaves than their parental lines, but expression of this trait was not influenced by season (Table 1). The inbreds CM135, CM136, CM137 and CM138 were almost comparable with other four genotypes used in the study which are the parental lines of hybrids Ganga Safed-2 and Ganga-5 for number of leaves per plant. Days to flowering, anthesis initiation was significantly earlier in kharif compared to spring-summer (Table 1). Genotypic differences were significant for days to $50 \%$ anthesis in both the seasons. Parental lines of PHM-1 and PHM-2 flowered earliest followed by CM500 and Cm600. Similarly, among parental lines of Ganga Safed-2, CM600 flowered earlier than Ganga5 parental line i.e., CM500 among single crosses, CM400xCM300 flowered earlier than CM202xCm111 though both flowered late compared to parental lines (Table 1). Days to flowering in order to synchronize the flowering of the parental lines of hybrids, it is essential to ascertain the days taken to flowering in both seasons, to plan the staggered sowing if there is non-synchronous flowering of parental lines for maximizing hybrid seed production. Flowering (days to $50 \%$ anthesis and silking) was early in kharif while it was late in spring-summer season (Table 1). Favorable and high ambient temperatures of $21-33{ }^{\circ} \mathrm{C}$ in kharif favoured early flowering, whereas low ambient temperatures in spring-summer caused prolonged vegetative phase thus prolonging days to flowering initiation (Table 2). Tamura et al., (1989) observed that development of silk and air temperature followed a sigmoid curve. Dubureq et al., (1983) reported that genotypic differences for days taken to tassel initiation and silk appearance were predominant over environmental factors. A similar Trend was observed for days to 50 per cent silking where silk appearance was early in kharif than in spring-summer (Table 1). Days to 50 per cent silking was earliest in CM136 in both the seasons. Among parental lines, CM138 had slightly delayed silking in both the seasons. Parental lines of Ganga Safed-2 and Ganga-5 followed a similar trend for days to 50\% silking. Anthesis duration was influenced by seasonal variations was pronounced effect in spring-summer, where it was longer due to favorable temperatures during flowering (Table 1). Shorter duration of anthesis of some genotypes in springsummer was due to poor crop growth. Genotypic differences were non-significant among seasons (Table 1). Duration of anthesis was longer in single crosses and ranged from 7.3 to 10 days. Inbred line CM136 has shorter duration of anthesis in both the seasons. Duration of silking among the 8 genotypes of maize exhibited marked effect of seasons with the values ranging from 10-11 days (Table 1). Silking duration was longer during spring summer compared to that of kharif seasons. Single crosses had longest silk receptivity (Table 1). Metereological parameters have immense effect on duration of pollen viability and silk receptivity, which are adversely affected by high temperatures and $\mathrm{RH}$ and longer duration of sunshine. In the present study, there are marginal differences among genotypes for duration of anthesis of genotypes in both seasons. But, durations of silk receptivity exhibited pronounced effect of seasons, with longest duration in springsummer (11 days) (Table 1). Aldrich et al., (1975) reported that adverse environmental conditions like hot and dry winds hastened silk drying. Presolska (1989) also observed that maize silks were receptive from 7 days up to 11 days under favorable conditions. 
Table.1 Flowering and Synchronization and plant growth of maize as influenced by different genotypes and seasons

\begin{tabular}{|c|c|c|c|c|c|c|c|c|c|c|c|c|c|c|}
\hline \multirow[t]{2}{*}{ Genotype } & \multicolumn{2}{|c|}{$\begin{array}{l}\text { Plant height } \\
\text { (cm) }\end{array}$} & \multicolumn{2}{|c|}{$\begin{array}{l}\text { Number of } \\
\text { leaves/plant }\end{array}$} & \multicolumn{2}{|c|}{$\begin{array}{l}\text { Days to } 50 \% \\
\text { anthesis }\end{array}$} & \multicolumn{2}{|c|}{$\begin{array}{c}\text { Days to } 50 \% \\
\text { silking of maize }\end{array}$} & \multicolumn{2}{|c|}{$\begin{array}{l}\text { Duration of anthesis } \\
\text { (no. of days) }\end{array}$} & \multicolumn{2}{|c|}{$\begin{array}{l}\text { Duration of } \\
\text { silking (no of } \\
\text { days) }\end{array}$} & \multicolumn{2}{|c|}{ Seed yield (g/cob) } \\
\hline & $\begin{array}{l}\text { Spring - } \\
\text { Summer }\end{array}$ & Kharif & $\begin{array}{l}\text { Spring - } \\
\text { Summer }\end{array}$ & Kharif & $\begin{array}{l}\text { Spring - } \\
\text { Summer }\end{array}$ & Kharif & $\begin{array}{l}\text { Spring - } \\
\text { Summer }\end{array}$ & Kharif & $\begin{array}{l}\text { Spring - } \\
\text { Summer }\end{array}$ & Kharif & $\begin{array}{l}\text { Spring - } \\
\text { Summer }\end{array}$ & Kharif & $\begin{array}{l}\text { Spring - } \\
\text { Summer }\end{array}$ & Kharif \\
\hline CM 600 & 145.1 & 142.1 & 9.9 & 10.7 & 75.7 & 54.2 & 79.9 & 53.1 & 7.4 & 6.1 & 8.9 & 7.9 & 28.9 & 27.6 \\
\hline CM400xCM300 & 163.5 & 172.9 & 11.8 & 12.5 & 78.9 & 56.9 & 84.3 & 56.3 & 8.5 & 7.3 & 11.9 & 11.4 & 37.1 & 34.5 \\
\hline CM500 & 159.3 & 151.7 & 10.6 & 10.8 & 76.1 & 55.0 & 80.9 & 54.8 & 7.9 & 6.5 & 11.7 & 10.5 & 32.3 & 31.9 \\
\hline CM202xCM111 & 165.0 & 180.1 & 12.4 & 13.4 & 83.7 & 57.6 & 88.6 & 58.5 & 9.2 & 10.0 & 12.6 & 12.3 & 40.0 & 36.6 \\
\hline CM 135 & 141.4 & 154.7 & 9.7 & 11.4 & 73.5 & 53.4 & 81.0 & 53.7 & 7.1 & 6.1 & 11.3 & 10.7 & 33.4 & 32.9 \\
\hline CM 136 & 140.7 & 154.0 & 9.4 & 11.2 & 72.2 & 52.1 & 80.3 & 53.0 & 6.9 & 5.7 & 11.0 & 10.4 & 33.0 & 32.6 \\
\hline CM 137 & 144.8 & 155.4 & 10.5 & 11.6 & 75.3 & 53.7 & 81.5 & 55.1 & 7.7 & 6.4 & 11.4 & 10.8 & 34.4 & 34.0 \\
\hline CM 138 & 142.8 & 154.8 & 10.3 & 11.4 & 74.7 & 53.5 & 82.5 & 55.2 & 7.3 & 6.2 & 11.6 & 11.0 & 33.8 & 33.1 \\
\hline MEAN & 150.3 & 158.2 & 10.6 & 11.6 & 76.3 & 54.6 & 82.3 & 55.0 & 7.8 & 6.0 & 11.3 & 10.6 & 34.1 & 32.9 \\
\hline C.D.(0.05) & 2.44 & 1.16 & 1.11 & 0.53 & 2.32 & 1.24 & 2.80 & 2.89 & 1.05 & 0.90 & 1.40 & 0.63 & 2.01 & 2.38 \\
\hline
\end{tabular}

Table.2 Days to flowering of parental lines of maize hybrids in different seasons

\begin{tabular}{|l|l|l|l|l|l|l|}
\hline \multicolumn{1}{|c|}{ Hybrid } & \multicolumn{3}{c|}{ Spring-Summer } & \multicolumn{2}{c|}{ Kharif } \\
\cline { 2 - 7 } & Female & Male & $\begin{array}{c}\text { Differences between } \\
\text { male and female }\end{array}$ & Female & \multicolumn{1}{c|}{$\begin{array}{c}\text { Male } \\
\text { male and female }\end{array}$} \\
\hline $\begin{array}{l}\text { Ganga-5 } \\
\text { [(CM202xCM111)xCM500] }\end{array}$ & 85 & 72 & 13 & 62 & 55 & 7 \\
\hline $\begin{array}{l}\text { Ganga safed-2 } \\
\text { [(CM400xCM300)xCM600] }\end{array}$ & 83 & 74 & 9 & 57 & 53 & 4 \\
\hline $\begin{array}{l}\text { Pusa Hybrid Makka-1 } \\
\text { (CM135xCM136) }\end{array}$ & 75 & 74 & 1 & 54 & 52 & 2 \\
\hline $\begin{array}{l}\text { Pusa Hybrid Makka -2 } \\
\text { (CM137xCM138) }\end{array}$ & 74 & 72 & 2 & 58 & 54 & 4 \\
\hline
\end{tabular}


Table.3 Flowering behavior and seed characters of maize genotypes in different seasons

\begin{tabular}{|c|c|c|c|c|c|}
\hline \multirow[t]{2}{*}{ Characters } & \multicolumn{2}{|c|}{$\begin{array}{c}\text { Flowering behaviour of maize } \\
\text { genotypes in different seasons } \\
\text { with relation to ambient } \\
\text { temperature an R.H. }\end{array}$} & \multirow[t]{2}{*}{ characters } & \multicolumn{2}{|c|}{$\begin{array}{l}\text { Seed characters of maize } \\
\text { genotypes* in different } \\
\text { seasons. }\end{array}$} \\
\hline & Spring & Kharif & & Spring & Kharif \\
\hline Days to $50 \%$ anthesis* & 76.3 & 54.6 & Seed yield $(\mathrm{g} / \mathrm{cob})^{*}$ & 34.1 & 32.9 \\
\hline Days to $50 \%$ silking* & 82.3 & 55 & Date of sowing & Feb.8 & June 28 \\
\hline Duration of anthesis (days)* & 7.8 & 6.8 & Harvesting date & June 22 & Oct. 17 \\
\hline Duration of silking (days)* & 11.3 & 10.6 & Days from flowering to maturity & $40-60$ & 40-50 \\
\hline Date of sowing & Feb. 8 & June 28 & Mean temperature $\left({ }^{\circ} \mathrm{C}\right) * *$ & 32.5 & 27.0 \\
\hline Mean temperature $\left({ }^{\circ} \mathrm{C}\right)^{* *}$ & 32.5 & 27.0 & Temperature range $\left({ }^{\circ} \mathrm{C}\right) * *$ & $25-40$ & 21-33 \\
\hline Temperature range $\left({ }^{0} \mathrm{C}\right)^{* * *}$ & $25-40$ & $23-31$ & Mean relative humidity $(\%)^{* *}$ & 50.0 & 72.5 \\
\hline Mean R.H. $(\%)^{* *}$ & 44.0 & 83.0 & Relative humidity range $(\%)^{* *}$ & $34-66$ & $60-85$ \\
\hline Relative humidity range $(\%)^{* * *}$ & $28-60$ & $78-88$ & Total rainfall $(\mathrm{cm})^{* *}$ & 10.7 & 66.1 \\
\hline Total rainfall $(\mathrm{cm})$ & - & 35.8 & \multirow{2}{*}{\multicolumn{3}{|c|}{$\begin{array}{l}\text { *Means values over } 8 \text { genotypes ( } 6 \text { inbred lines and } 2 \text { single } \\
\text { crosses). } \\
\text { **Temperature, R.H. and rainfall from flowering to harvest. }\end{array}$}} \\
\hline \multicolumn{3}{|c|}{$\begin{array}{l}\text { *Means values over } 8 \text { genotypes ( } 6 \text { parental and } 2 \text { single crosses). } \\
\text { **Temperature, R.H. and rainfall during flowering. }\end{array}$} & & & \\
\hline
\end{tabular}


Duration of anthesis and silk receptivity was longest in single crosses and parental lines but poor growth and delayed flowering in CM138 and CM137 lowered the duration of silk receptivity in these 2 genotypes. Synchronization of anthesis in male and female parental lines in pre-requisite for successful hybrid seed production. Nonsynchronization of flowering in parental lines i.e. differences in days to anthesis in male and silking in female was more in spring-summer (1-13 days) than in kharif (2-7 days) (Table 2). Parental lines of Ganga-5 (7-13 days) and Ganga safed-2 (4-9 days) hybrids exhibited non-synchrony. The difference in flowering of parental lines of Pusa Hybrid Makka-1 was least (1-2 days) and the parental lines of PHM1 also showed synchrony in both the seasons. Thus, seed production of PHM-1 and PHM-2 can be successfully undertaken in both the seasons but for hybrids Ganga safed-2 and Ganga -5 staggered planting of parental lines will be required to ensure perfect nicking in spring-summer as the problem of non-synchronization of flowering was more in this season. Non-synchronization of flowering by $2-4$ days between the male and female parents can also be bridged by nutrient management like application of nitrogen to late parent (Sharma 1993). Problem of non-synchronization was least in newly developed single crosses PHM-1 and PHM-2 which had opened up possibilities of their seed production in North India. The data on seed yield per cob the different maize genotypes in both the seasons are presented in Table 1. Effect of seasons was pronounced in seed yields with highest yield in spring-summer season. Genotypic differences were also significant for this trait with single crosses exhibiting maximum seed yield per cob in both the seasons. Seed yield of open-pollinated varieties (CM600 and Cm500) was comparatively lower than other parental lines (Table 1).

\section{References}

Aldrich, S.R.; Scott, W.O. and Leng, E.R. (1975).
Modern corn production, 2nd edition. A and P Pub. Champaign, Illinois. 377p.

Cooper, P. J.M. and Low, R. (1977). The effect and importance of soil temperature in determining the early growth vigour and final grain yields of hybrid maize in the highlands of Kenya. World Meteorological Organization Agrometeorology of the Corn Crop. 11: 265 - 281.

Duburcq, J. B.; Bonhomme, R. and Derieux, M. (1983). Duration of the vegetative and reproductive periods in maize Agronomie. 3(10): $914-946$.

Hollinger, S.E. (1981). Environmental effects on corn ear morphology, planting to silking. Dissertation Abs. Int. Biol. Sci. Engg. 42(5): 1700.

GFO. 2012. Consumer resources for corn. Grain Farmers of Ontario (www.gfo.ca/About UsMain/Community/ConsumerResourcesf orCorn.aspx). Accessed May 9, 2012.

Kaur, G.P., Dhillon, M. and Dhillon, B.S. (1986). Performance of maize varieties in monsoon and winter seasons. Ind. J. Ecol. 13(2): 277-280.

Panse, V.C. and Sukhatme, P.T. (1967). Group of experiments. In: Statistical Methods for Agricultural Workers, $2^{\text {nd }}$ edition. Indian Council of Agricultural Research, New Delhi. pp. 258-269.

Tamura, Y.; Takeawa, K.; Konna, T.; Ona. S.; Seino, H. and Monma, E. (1989). Production of silking stage in maize based on temperature response evaluated by a non-parametric method. Japanese J. Crop Sci. 58(1): 48-54.

USDA. 2012. World corn production, consumption, and stocks. United States Department of Agriculture: Foreign Agricultural Service website (www.fas.usda.gov/psdonline/psdreport.as px). Accessed May 9, 2012.

\section{How to cite this article:}

Vikas Verma, B. Ramesh, C.L. Maurya, S.S. Gaurav, Janardan Kumar andAshoka Chaudhary. 2018. Evaluation of Different Genotypes of Maize (Zea mays L.) on Plant Growth, Flowering, Synchronization and Seed Yield in Relation to Environmental Factors and Seasons. Int.J.Curr.Microbiol.App.Sci. 7(07): 1731-1736. doi: https://doi.org/10.20546/ijcmas.2018.707.205 